\title{
Humans as predators on rocky reefs in New South Wales, Australia
}

\author{
M. J. Kingsford, A. J. Underwood, S. J. Kennelly* \\ Institute of Marine Ecology, Zoology Building AO8, University of Sydney, NSW 2006, Australia
}

\begin{abstract}
Multifactorial sampling designs were used to describe the activities of humans on rocky reefs. Intensive studies around Sydney and broad scale surveys along $1000 \mathrm{~km}$ of the coast of New South Wales (NSW), Australia, recorded the amount of fish and exploitation of intertidal organisms by humans. Sparid and girellid fish were taken in large numbers by fishermen. Intertidal ascidians, crabs and gastropods were primarily used by fishermen as bait. The activity of humans affecting the shore was greatest from late morning to dusk on weekdays and weekends of school holidays. No major effects of tide were detected. Numbers of people affecting or not affecting the shore (e.g. sunbathers and walkers) were greatest in summer. The distribution of fishermen was patchy on scales of 50 and $100 \mathrm{~m}$ and the effects of fishing and gathering bait may therefore be concentrated in particular small areas. Broadscale surveys along the coast of NSW in summer and winter detected no differences, in numbers of people affecting the shore, between widely separated locations at varying distances from highly populated areas. People in NSW are probably sufficiently mobile to create this pattern. Large differences were found among sites separated by 1 to $10 \mathrm{~km}$ at each location along the coast of NSW. Humans have a potentially important direct effect on populations of organisms and indirect effects on structure of inshore assemblages of species. Multiple sanctuaries are recommended to determine the effect of exploitation by humans. Moreover, additional information is required on the ecology of species particularly subject to predation by humans
\end{abstract}

\section{INTRODUCTION}

In Australia, fishing is one of the most popular recreational activities in coastal environments (Yapp 1986). Although a large number and variety of fish and other organisms are exploited, there is little information on the numbers and types affected, or on how human activity affects the organisms. There have been surveys of the activities of recreational fishermen in lakes and rivers (Beamish 1986, Higgins 1986, Rice 1986, Hume 1987, Gehrke 1988), but with a few exceptions (e.g. Fedler \& Ditton 1986, Duran et al. 1987), information about human predation is sparse in marine environments. This is especially true in Australia (but see Catterall \& Poiner 1987, Underwood \& Kennelly 1990).

There is intense recreational fishing activity along the coast of New South Wales (NSW), Australia's most heavily populated coastline (Gartside 1986, Yapp 1986). People can affect organisms on the shore by

\footnotetext{
- Present address: Fisheries Research Institute, New South Wales Agriculture \& Fisheries, PO Box 21, Cronulla, NSW 2230, Australia
}

catching fish, gathering organisms from intertidal areas as food, for bait, or as pets for aquaria, or by inadvertently or intentionally (e.g. children) killing organisms, and scientists remove large numbers of particular species in some areas. Accordingly, not only is the catch of individual species of potential concern, but the removal of some organisms may cause changes in the ecology of local reefs (e.g. Castilla \& Duran 1985, Moreno et al. 1986, Hockey et al. 1988). For example, gastropods, sought after by some, are important grazers of algae on reefs. Their removal facilitates the growth of algae (Underwood 1980, 1985, Underwood \& Jernakoff 1981, Hockey \& Bosman 1986) which can result in a series of other changes (Underwood et al. 1983, Underwood \& Jernakoff 1984).

Here, we investigated the patterns of activity of humans on rocky reefs. Because human activities are very variable, we attempted to establish which factors were important on a local scale before embarking upon a survey over a broad spatial scale. Preliminary sampling (Underwood \& Kennelly 1990) was used to design a sampling programme to determine the activity of people affecting the shore at different times and states 
of the tide. Fishing may be, or may be thought to be, best at a particular time of the day or state of the tide. Moreover, intertidal organisms (for bait or food) may be most accessible during low tide (e.g. Hockey \& Bosman 1986, Duran et al. 1987). Other obvious problems in estimating human impact were that intensity of fishing increases during the school holidays, and at weekends compared to weekdays, and that the number of fishermen may vary among locations (Underwood \& Kennelly 1990).

NSW has a long coastline, extending over $12^{\circ}$ of latitude (Fig. 1). Regional differences may be found for a number of reasons. Intensity of collecting or fishing activity may correlate with density of people (Hockey

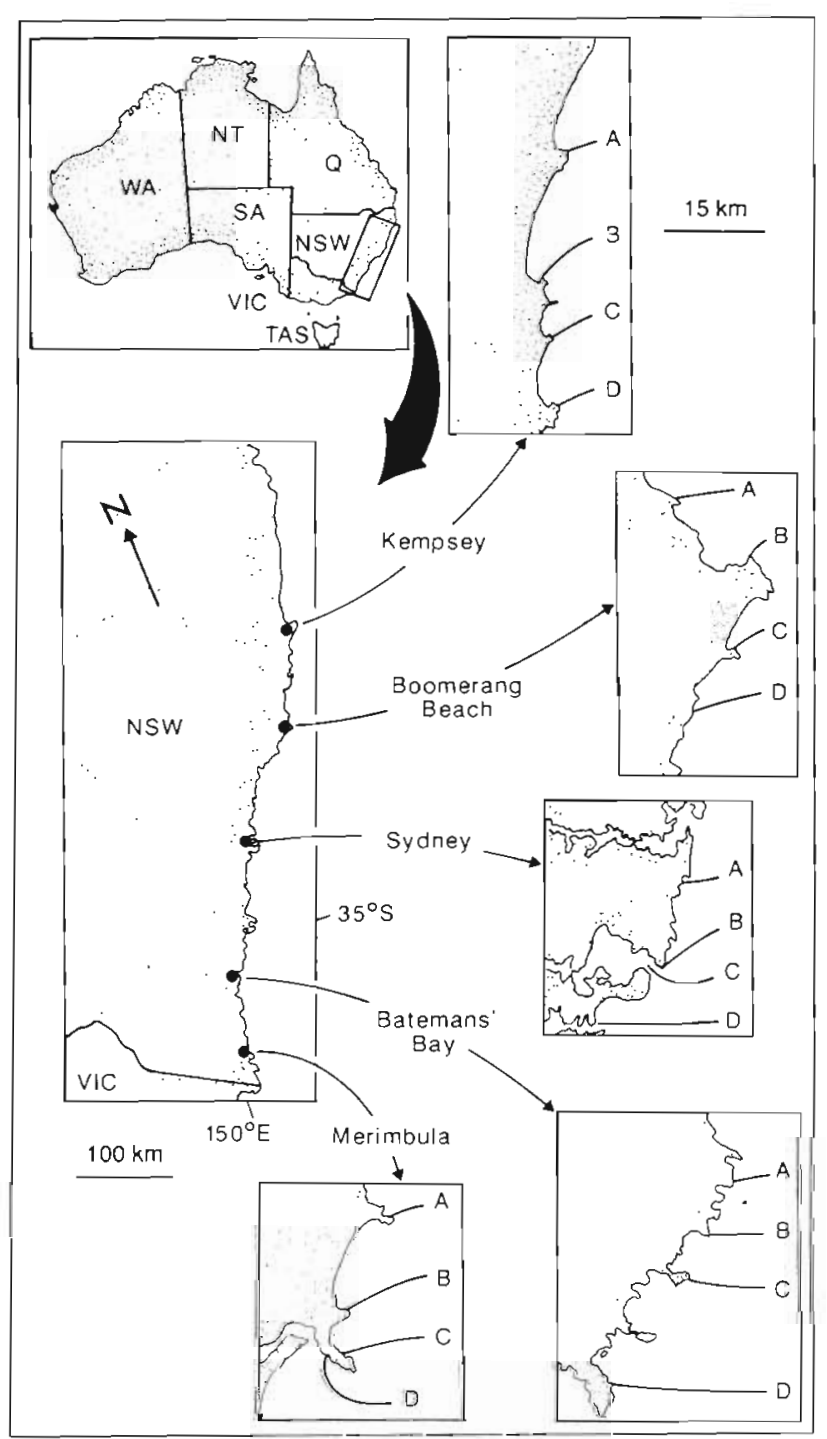

Fig. 1. Study areas in Australia, with locations in New South Wales where activities of humans on rocky shores were surveyed. Detailed studies were conducted at 2 ( $A$ and $D)$ of the 4 sites in Sydney; 4 sites within each location along the coast were surveyed et al. 1988). The catch of recreational fishermen may be affected by regional differences in types, abundance and behaviour of fish (e.g. Cowan 1985, Choat \& Ayling 1987, Gehrke 1988). For these reasons, widely spaced locations were sampled.

Our specific goals were to identify the organisms most affected by humans, to obtain estimates of the magnitude of exploitation and to provide guide-lines for future surveys to lay a rational and quantitative foundation for management and conservation of the resources used in recreational fishing.

\section{MATERIALS AND METHODS}

Sampling procedure. For all of the sampling designs, people were recorded at sites on rocky shores (1 to $3 \mathrm{~km}$ long). Counts were made of people not directly affecting the shore (e.g. walkers, sunbathers, surfers) and people directly affecting organisms on the shore, including fishermen, spear-fishermen, foragers (anyone taking organisms for food or other purposes not directly connected with fishing) and collectors of bait. In some cases, the positions of fishermen were recorded on a detailed map for assessment of small-scale patterns of distribution.

The following information was requested from people affecting the shore: (1) number and identification of organisms caught and, where possible, the standard lengths of fish; (2) the type of bait used and whether it came from the shore; (3) hours spent fishing. Rock pools in the immediate area of fishermen were scanned for fish and other organisms captured and discarded, but not mentioned during interviews.

Some fishermen used algae (e.g. Ulva spp., Enteromorpha spp.) as bait for herbivorous fish (e.g. Girellidae). Such algae were often scraped from rocks, using metal scrapers attached to footwear; thus it was impossible to record the actual quantities taken. Accordingly, data were recorded as numbers of fishermen with intertidal algae.

Sampling designs. A summary of the sampling designs used in this study is given in Table 1. Underwood \& Kennelly (1990) demonstrated that the activity of people on rocky shores was reduced on rainy days. In all of the surveys described in this paper we avoided rainy days. Patterns on rocky reefs around Sydney were studied in detail to enable planning of a broadscale study. In all designs, replicates were independent counts on randomly chosen days representing the desired conditions of tide, weather and so forth.

Human activity over a 14 mo period was compared in school holidays only (Design A). People were counted at different times of day, states of the tide and at different sites, each characterised by sandstone cliffs and fringing 
Table 1. Sampling designs used in this project (brackets denote the factor in which a term is nested). In Designs A and $B$, all sources of variation were fixed factors; Location and Site were random factors in Designs C and D

\begin{tabular}{|c|c|}
\hline \multicolumn{2}{|c|}{ Design A: At Bondi and Cronulla in Sydney, 1986-1988 } \\
\hline Source of variation & Levels \\
\hline Survey & $\begin{array}{l}\text { Summer 1986-87, winter } 1987 \text {, } \\
\text { summer } 1987-88\end{array}$ \\
\hline Time of day & $\begin{array}{l}\text { Early }(06: 00-08: 00 \mathrm{~h}) \text {, middle }(12: 00- \\
13: 00 \mathrm{~h}) \text {, late }(15: 30-19: 00 \mathrm{~h})\end{array}$ \\
\hline Tide & High, low \\
\hline Site & 2 \\
\hline Replicates & 2 \\
\hline \multicolumn{2}{|c|}{ Design B: At Bondi and Cronulla in Sydney, 1986-1987 } \\
\hline Source of variation & Levels \\
\hline Time of day & Early, middle, late (as above) \\
\hline Tide & High, low \\
\hline Holiday & School holiday, term-time \\
\hline Site & 2 \\
\hline Replicates & 2 \\
\hline \multicolumn{2}{|c|}{ Design C: At 5 shores around Sydney, 1988-1989 } \\
\hline Source of variation & Levels \\
\hline Week & Weekdays, weekend \\
\hline Site & $\begin{array}{l}\text { Cape Banks, Bare Island, Bondi, } \\
\text { Cronulla, Hacking Point }\end{array}$ \\
\hline Replicates & 3 \\
\hline \multicolumn{2}{|c|}{ Design D: Along the coast of NSW, 1988} \\
\hline Source of variation & Levels \\
\hline Location & $\begin{array}{l}\text { Merimbula, Batemans Bay, Sydney, } \\
\text { Boomerang Beach, Kempsey }\end{array}$ \\
\hline Site (Locati & Four randomly chosen sites, A-D \\
\hline Replicates & 3 \\
\hline
\end{tabular}

rocky reef. The times of day given in Table 1 are for summer only. Winter 'early' was 07:30 to 09:00 h and late $16: 30$ to $17: 30 \mathrm{~h}$, as determined by the hours of darkness. Counts were only made on week days.

Design B compared numbers of people in and out of school holidays and was completed in summer 1986-87 (December to February) and winter 1988 (June to August). Data from school holidays during winter and summer 1986-87 were from Design A. The reef was partitioned into $50 \mathrm{~m}$ areas and numbers of fishermen were analysed and compared to a Poisson frequency distribution. Because patchiness is a function of the size of the sample unit, the data were also analysed using $100 \mathrm{~m}$ lengths of shore.

A pilot study in winter 1987 showed a trend that the numbers of recreational fishermen at Bondi and Cronulla differed between weekdays (mean number of fisherman per $2 \mathrm{~km}=2.5$ ) and weekends (mean $=9.5$, $\mathrm{n}=8 \mathrm{~d} ; t=2, \mathrm{p}>0.05$ ). This pattern was examined in detail at 5 sites (see Table 1: Design $C$ ). Designs $A$ and $B$ indicated that the activity of humans was significantly less early in the morning. For this reason, people were counted only after mid-morning.
In Design $\mathrm{D}$, the activity of humans on rocky shores was examined along $1000 \mathrm{~km}$ of the coast of NSW in the summer and winter of 1988 . The 2 surveys were on weekdays during term-time, later than mid-morning. Differences were found among sites within the vicinity of Sydney. People were therefore counted at 4 sites within each location to allow for this variation (see Fig. 1). The sites at each location were randomly chosen from those that were exposed or partially exposed to the open sea from at least one compass direction. Most sites were rocky reefs surrounded by sandstone cliffs or steep hills.

\section{RESULTS}

\section{Activity of humans - local scale}

The smallest numbers of people affecting the shore were found early in the morning, in all surveys from 1986 to 1988 . Although there was a trend for more activity late in the day, this did not differ significantly from the middle of the day (Fig. 2, Table 2). No differences in numbers of people were found between the 3 surveys at different states of the tide nor among sites. Maximal numbers of people affecting the shore were 25 per $2 \mathrm{~km}$. Numbers of fishermen per $2 \mathrm{~km}$ varied among times; greater numbers were found late in the day than early in the morning (Table 2). Numbers also varied between locations; Bondi (mean $=6.9$ ) had more fishermen than Cronulla (mean $=4.3 ;$ Table 2 ). The largest number of fishermen per $2 \mathrm{~km}$ was 21 . No interactions were found between the 4 factors indicating consistent patterns of use of the 2 shores (Table 2; people affecting shore and fishermen). The residual
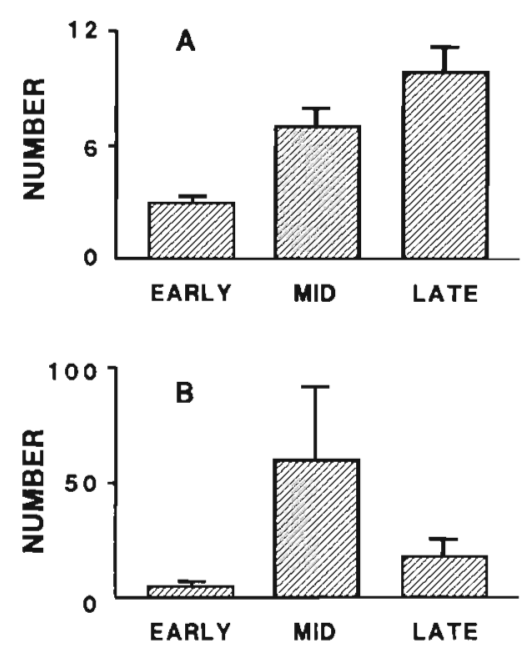

Fig. 2. Numbers of people (A) affecting the shore and (B) not affecting the shore at different times of day (means + SE); data from Design A (Table 1) 
Table 2. Analyses of numbers of people visiting shores, sampled using Design A (see Table 1). All analyses were done using untransformed data. $C=$ Cochran's test; in this and subsequent tables, ${ }^{p} p<0.05 ; \cdots p<0.01 ; \cdots p<0.001 ; n s, p>0.05$

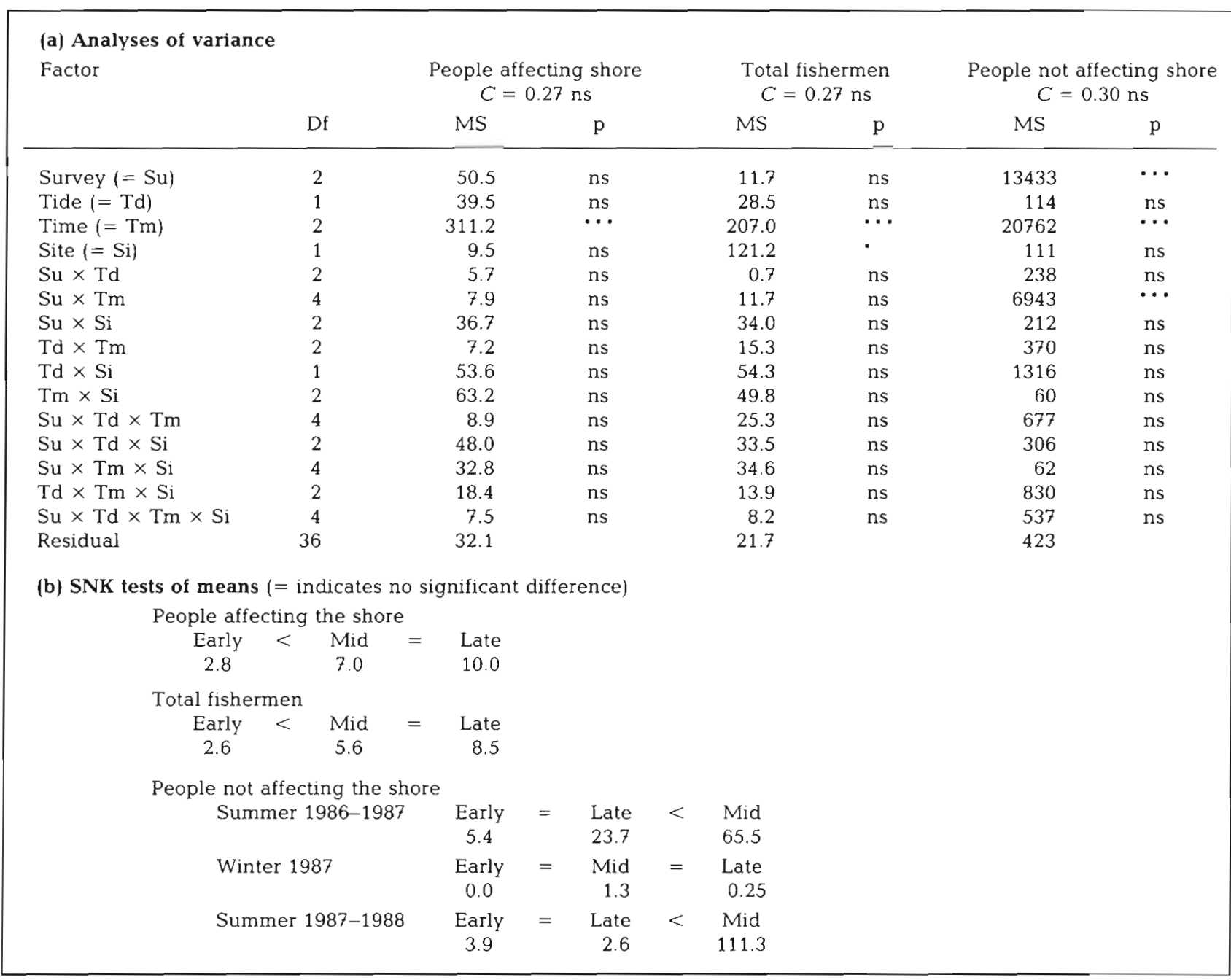

variance was, however, great in both analyses, reflecting a large variance among replicates and therefore considerable patchiness in use of these habitats.

The numbers of fishermen did not correspond to rates of catching fish. Fishermen appeared to be just as likely to catch fish early as late in the day (Fig. 3). Moreover, no significant differences were found between numbers of fish caught during high or low tide. Small numbers of fishermen early in the day reflect a reluctance to fish early in the morning.

Few foragers were counted in the 3 surveys; summer 1986-87, 1; winter 1987, 12; summer 1987-88, 12. A total of 63 divers (including spearfishermen) were observed during summer 1986-87, 10 during the winter and 54 in summer 1988. The potential impact of divers was therefore greatest during the warmest months of the year. No divers were counted early in the morning. Most of the divers and spearfishermen $(81.2 \%)$ were
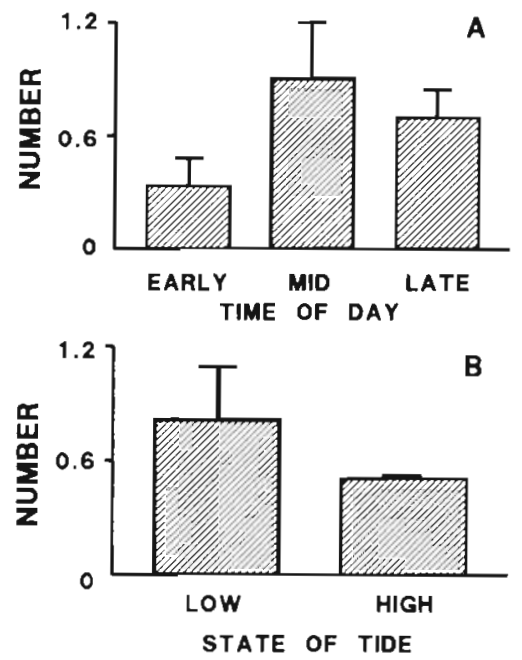

Fig. 3. Numbers of fish captured per hour (A) at different times of the day and $(B)$ at different states of the tide (means $+\mathrm{SE}$ ); data from Design A (Table 1) 
Table 3. Analyses of mean numbers of people per $2 \mathrm{~km}$ (see Design B, Table 1)

\begin{tabular}{|c|c|c|c|c|c|c|c|c|c|c|c|c|c|}
\hline \multicolumn{14}{|c|}{ (a) Analyses of variance [untransformed data in summer, transformed to $\ln (x+1)$ in winter. $C$ is Cochran's test] } \\
\hline & & \multicolumn{8}{|c|}{ Summer } & \multicolumn{4}{|c|}{ Winter } \\
\hline \multirow[t]{3}{*}{ Factor } & \multirow[b]{3}{*}{ Df } & \multirow{2}{*}{\multicolumn{3}{|c|}{$\begin{array}{c}\text { People affecting } \\
\text { shore } \\
C=0.2 \text { ns }\end{array}$}} & \multirow{2}{*}{\multicolumn{3}{|c|}{$\begin{array}{l}\text { Total fishermen } \\
\qquad C=0.3 \mathrm{~ns}\end{array}$}} & \multirow{2}{*}{\multicolumn{2}{|c|}{$\begin{array}{l}\text { People not } \\
\text { affecting shore } \\
C=0.46 \mathrm{~ns}\end{array}$}} & \multirow{2}{*}{\multicolumn{2}{|c|}{$\begin{array}{l}\text { People affecting } \\
\text { shore } \\
C=0.45 \mathrm{~ns}\end{array}$}} & \multirow{2}{*}{\multicolumn{2}{|c|}{$\begin{array}{c}\text { Total fishermen } \\
\qquad C=0.54^{\cdots}\end{array}$}} \\
\hline & & & & & & & & & & & & & \\
\hline & & MS & $\mathrm{p}$ & & MS & & $\mathrm{p}$ & MS & $\mathrm{p}$ & MS & $\mathrm{p}$ & MS & $\mathrm{p}$ \\
\hline Tide $(=$ Td) & 1 & 3.1 & ns & & 2.7 & & $\mathrm{~ns}$ & 260 & $\mathrm{~ns}$ & 3.8 & $\cdots$ & 2.8 & $\cdots$ \\
\hline Time $(=\mathrm{Tm})$ & 2 & 253.2 & $\cdots$ & & 208.5 & & $\cdots$ & 11530 & $\cdots$ & 1.7 & $\cdot$ & 2.0 & $\cdots$ \\
\hline Holiday $(=\mathrm{H})$ & 1 & 74.3 & ns & & 41.4 & & $\mathrm{~ns}$ & 1364 & $\mathrm{~ns}$ & 2.3 & $\cdot$ & 2.2 & $\cdot$ \\
\hline Site $(=\mathrm{Si})$ & 1 & 10.5 & ns & & 95.8 & & $\cdot$ & 75 & ns & 3.0 & $\cdots$ & 5.5 & $\cdots$ \\
\hline $\mathrm{Td} \times \mathrm{Tm}$ & 2 & 12.1 & ns & & 25.9 & & ns & 350 & ns & 0.4 & ns & 0.8 & ns \\
\hline $\mathrm{Td} \times \mathrm{H}$ & 1 & 16.4 & ns & & 14.7 & & ns & 51 & ns & 0.02 & ns & 0.6 & ns \\
\hline $\mathrm{Td} \times \mathrm{Si}$ & 1 & 5.0 & ns & & 5.7 & & $\mathrm{~ns}$ & 1068 & ns & 0.6 & ns & 0.6 & ns \\
\hline $\mathrm{Tm} \times \mathrm{H}$ & 2 & 0.5 & ns & & 0.5 & & ns & 302 & ns & 0.3 & ns & 0.4 & ns \\
\hline $\mathrm{Tm} \times \mathrm{Si}$ & 2 & 141.2 & $\cdots$ & & 109.4 & & $\cdots$ & 166 & ns & 0.1 & ns & 0.3 & $\mathrm{~ns}$ \\
\hline $\mathrm{H} \times \mathrm{Si}$ & 1 & 22.3 & ns & & 2.7 & & $\mathrm{~ns}$ & 172 & ns & 0.4 & ns & 0.003 & $\mathrm{~ns}$ \\
\hline $\mathrm{Td} \times \operatorname{Tm} \times \mathrm{H}$ & 2 & 8.2 & ns & & 21.0 & & ns & 47 & ns & 0.2 & ns & 0.05 & ns \\
\hline $\mathrm{Td} \times \mathrm{Tm} \times \mathrm{Si}$ & 2 & 5.2 & ns & & 6.4 & & ns & 436 & $\mathrm{~ns}$ & 0.4 & ns & 0.1 & ns \\
\hline $\mathrm{Td} \times \mathrm{H} \times \mathrm{Si}$ & 1 & 0.01 & ns & & 2.9 & & ns & 0.1 & $\mathrm{~ns}$ & 0.1 & ns & 0.01 & ns \\
\hline $\mathrm{Tm} \times \mathrm{H} \times \mathrm{Si}$ & 2 & 2.0 & ns & & 5.8 & & ns & 1.4 & ns & 0.7 & ns & 0.3 & ns \\
\hline $\mathrm{Td} \times \mathrm{Tm} \times \mathrm{H} \times \mathrm{Si}$ & 2 & 5.0 & ns & & 2.2 & & ns & 185 & $\mathrm{~ns}$ & 0.5 & ns & 0.4 & $\mathrm{~ns}$ \\
\hline Residual & 24 & 19.4 & & & 13.2 & & & 763 & & 0.4 & & 0.3 & \\
\hline \multicolumn{14}{|c|}{ (b) SNK tests for summer analyses } \\
\hline \multicolumn{3}{|c|}{ People affecting the shore: } & $\begin{array}{c}\text { Early } \\
2.6\end{array}$ & $=$ & $\begin{array}{r}\text { Mid } \\
6.6\end{array}$ & $<$ & $\begin{array}{l}\text { Late } \\
10.6\end{array}$ & & & & & & \\
\hline \multicolumn{3}{|l|}{ Total fishermen } & $\begin{array}{c}\text { Early } \\
2.6\end{array}$ & $=$ & $\begin{array}{r}\text { Mid } \\
3.9\end{array}$ & $<$ & $\begin{array}{r}\text { Late } \\
9.4\end{array}$ & & & & & & \\
\hline \multicolumn{3}{|c|}{ People not affecting the shore } & $\begin{array}{c}\text { Early } \\
4.7\end{array}$ & $=$ & $\begin{array}{l}\text { Late } \\
17.6\end{array}$ & $<$ & $\begin{array}{l}\text { Mid } \\
56.3\end{array}$ & & & & & & \\
\hline
\end{tabular}

counted at Cronulla, but no consistent patterns were found according to state of the tide.

In winter (only), there were significantly more people affecting the shore in school holidays than during termtime (Table 3). Although significant differences were found between high and low tides in one survey (winter), there were only small differences between the means. These patterns were also found for fishermen (mean numbers per $2 \mathrm{~km}$ were 4.8 in holidays and 2.5 during term-time). The variances in the data for winter were, however, intractably heterogeneous and the results should be treated with caution.

The distribution of fishermen was patchy within sites, i.e. within each $2 \mathrm{~km}$ stretch of the coastline (Fig. 4). Particular areas of reef appeared to be favourite fishing spots and received much more attention from fishermen than other areas. The numbers of fishermen counted in $50 \mathrm{~m}$ areas along reefs (Fig. 4) were not consistent with a Poisson frequency distribution at Bondi $\left(\chi^{2}=42,5 \mathrm{df}\right.$, $\mathrm{p}<0.005)$ nor at Cronulla $\left(\chi^{2}=52,4 \mathrm{df}, \mathrm{p}<0.05\right)$ in summer 1988. Distributions were also patchy at $100 \mathrm{~m}$ intervals for Bondi $\left(\chi^{2}=1291,14 \mathrm{df}, \mathrm{p}<0.005\right)$ and
Cronulla $\left(\chi^{2}=38,6\right.$ df, $\left.\mathrm{p}<0.005\right)$. Frequency distributions indicated how clumped fishermen were in some areas (Fig. 5). The most popular areas of the Cronulla site were at the southern end in summer. Similarly, in winter 1987, the distribution of fishermen was patchy among $50 \mathrm{~m}$ and $100 \mathrm{~m}$ stretches of coastline at Bondi $\left(50 \mathrm{~m}, \chi^{2}=81,5 \mathrm{df}, \mathrm{p}<0.005 ; 100 \mathrm{~m}, \chi^{2}=1291,14 \mathrm{df}\right.$, $\mathrm{p}<0.005)$ and Cronulla $\left(50 \mathrm{~m}, \chi^{2}=23,2 \mathrm{df}, \mathrm{p}<0.005\right.$; $\left.100 \mathrm{~m}, \chi^{2}=22,4 \mathrm{df}, \mathrm{p}<0.005\right)$. Although some areas of rocky reef were ignored by fishermen, in summer and winter, other areas received concentrated attention. 'Favourite areas' were not always identical in winter and summer, possibly because rough seas cause some areas to be unsafe at some times of the year.

More people were found on the shore at weekends than on weekdays at 5 sites in the Sydney area (Fig. 6). Large differences were found between sites and these differences were consistent on weekdays and weekends (there was no interaction term; Table 4). The patterns described above were also found for recreational fishermen (Table 4).

The largest numbers of people who did not affect the 


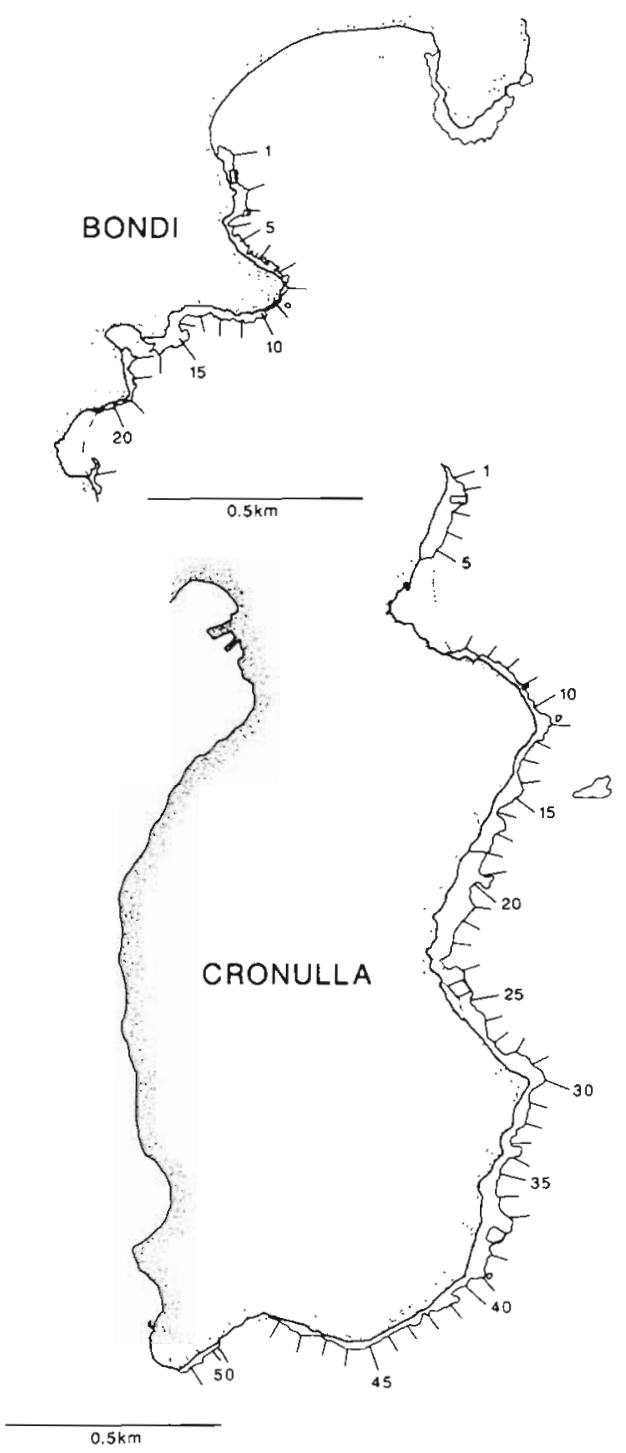

Fig. 4. Maps used to plot the small-scale distribution of fishermen at Bondi (upper) and Cronulla (lower) in Sydney during school holidays; sites are divided into $50 \mathrm{~m}$ lengths (every fifth one is numbered)
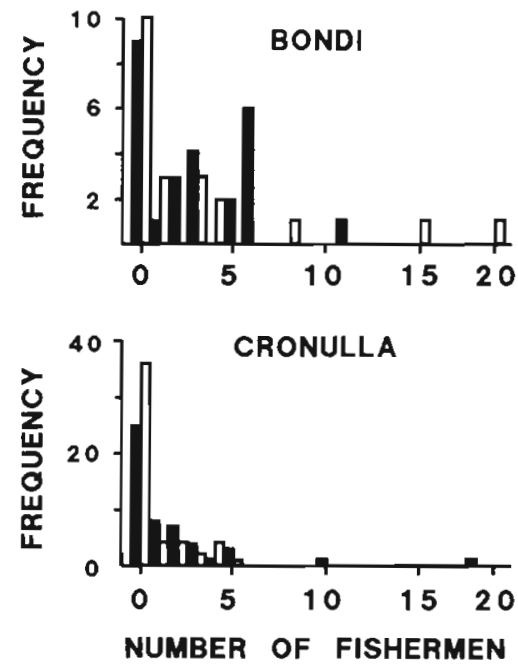

Fig. 5. Frequency distributions of numbers of fishermen per $50 \mathrm{~m}$ lengths (see Fig. 4) in summer (black bars) and winter (open bars) (1986-87) at 2 sites in Sydney

shore were found during the middle of the day; small numbers were found early and late in the day (Table 2 , Fig. 2). In winter, however, only 14 people were observed who did not affect the shore, causing a significant interaction between period and time (Table 2). Numbers did not vary according to the state of the tide. Large differences in the number of people not affecting the shore were found among surveys. Accordingly, the indirect effects of people on the shore (e.g. crushing organisms, littering) would be greatest during the summer. Differences in numbers of people were also found between summers (Table 2). No differences in numbers of people affecting the shore were detected between school holidays and term-time in summer 1986-87 (Table 3). Numbers were too small for formal analyses in winter 1987. No significant differences were found between weekdays and weekends, for people not affecting the shore, but significant differences were found among sites (Table 4). Walkers and sunbathers

Table 4. Analyses of mean numbers of people per $1 \mathrm{~km}$ of shore on weekends and weekdays (Design C, see Table 1) using untransformed data. Values for Cochran's test are given (C)

\begin{tabular}{|c|c|c|c|c|c|c|c|}
\hline \multirow[t]{2}{*}{ Factor } & \multirow[b]{2}{*}{ Df } & \multicolumn{2}{|c|}{$\begin{array}{l}\text { People affecting shore } \\
\qquad C=0.37 \mathrm{~ns}\end{array}$} & \multicolumn{2}{|c|}{$\begin{array}{l}\text { Total fishermen } \\
C=0.45 \mathrm{~ns}\end{array}$} & \multicolumn{2}{|c|}{$\begin{array}{l}\text { People not affecting shore } \\
\qquad C=0.46 \mathrm{~ns}\end{array}$} \\
\hline & & MS & $\mathrm{p}$ & MS & $\mathrm{p}$ & MS & $\mathrm{p}$ \\
\hline Weekend/Day $(=$ W) & 1 & 180.1 & $\cdot$ & 184.2 & $\cdots$ & 55 & ns \\
\hline Site $(=\mathrm{S})$ & 4 & 348.8 & $\cdots$ & 253 & $\cdots$ & 5284 & $\cdot$ \\
\hline $\mathrm{W} \times \mathrm{S}$ & 4 & 33.6 & $n s$ & 42.3 & ns & 58 & ns \\
\hline Residual & 20 & 34.6 & & 22.5 & & 1834 & \\
\hline
\end{tabular}




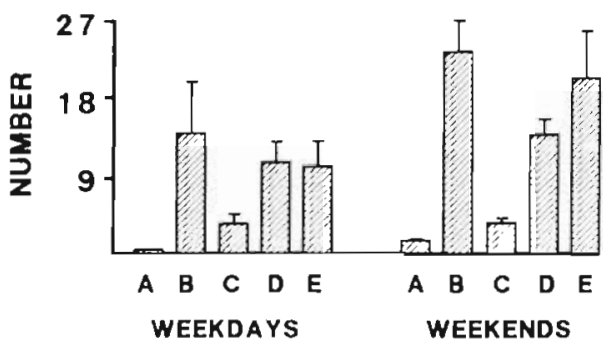

Fig. 6. Numbers of people affecting the shore on weekends and weekdays at 5 sites in Sydney (mean number per $1 \mathrm{~km}+\mathrm{SE}$ ) $\mathrm{A}=$ Cape Banks, $\mathrm{B}=$ Bare Island $\mathrm{C}=$ Bondi, $\mathrm{D}=$ Cronulla, $\mathrm{E}=$ Hacking Point were found in greatest numbers at Bare Island and the 2 sites near Cronulla regardless of whether it was during the weekend or on weekdays.

\section{Organisms affected by humans - local scale}

A variety of fish species was caught by recreational fishermen around Sydney (Table 5). A large proportion of the catch, in all surveys, was comprised by herbivorous girellid fishes; other groups included sparids, aplodactylids, chironemids and pomatomids (Table 5).

Table 5. Proportional representation (\% data) of fish captured by recreational fishermen in the Sydney area over a period of 24 mo (Designs A, B \& C as in Table 1)

\begin{tabular}{|c|c|c|c|c|c|}
\hline Group & Common name & $\begin{array}{l}\text { Summer } \\
1986-87\end{array}$ & $\begin{array}{c}\text { Winter } \\
1987\end{array}$ & $\begin{array}{l}\text { Summer } \\
1987-88\end{array}$ & $\begin{array}{c}\text { Winter } \\
1989\end{array}$ \\
\hline Girella spp. & Blackfish & 46.5 & 47.3 & 17.5 & 19 \\
\hline Acanthopagrus australis & Bream & 11.3 & 10 & 13.8 & 7.3 \\
\hline Chrysophrys auratus & Snapper & 0 & 0 & 4.6 & 1.5 \\
\hline Mugil cephalus & Mullet & 5.6 & 0 & 0 & 1 \\
\hline Sillago ciliata & Whiting & 2.1 & 0.9 & 6.5 & 1 \\
\hline Scorpis aquipinnis & Sweep & 5.6 & 0 & 0.9 & 17.7 \\
\hline Kyphosus sydneyanus & Drummer & 3.5 & 4.5 & 5.5 & 0.5 \\
\hline Aplodactylidae & Sea carp & 0.7 & 8.1 & 18.5 & 8.9 \\
\hline Scorpaena spp. & Rock cod & 9.9 & 10 & 0 & 1.5 \\
\hline Atypichthys strigatus ${ }^{\mathrm{a}}$ & Mado & 0.7 & 0 & 0 & 9.9 \\
\hline Ophthalmolepis lineolatus & Maori wrasse & 0.7 & 2.7 & 0 & 0.5 \\
\hline Gymnothorax spp. & Moray eel & 0.7 & 1.8 & 0 & 6.3 \\
\hline Pomatomus saltator & Tailor & 11.3 & 3.6 & 7.4 & 0 \\
\hline Monacanthidae & Leatherjackets & 0.7 & 0 & 1.9 & 4.1 \\
\hline Plectorhynchus spp. & Sweetlips & 0 & 0 & 1.8 & 0 \\
\hline Platycephalus spp. & Flathead & 0 & 1.9 & 0 & 0 \\
\hline Pseudocaranx dentex & Trevally & 0 & 8.1 & 2.8 & 0 \\
\hline Pleuronectidae & Flounder & 0 & 0 & 0.9 & 0.5 \\
\hline Gerres subfaciatus & Biddy & 0 & 0 & 0.9 & 0 \\
\hline Torquigener & Toadfish & 0 & 0 & 9.2 & 0 \\
\hline Microcanthus strigatus & Stripey & 0 & 0 & 0.9 & 0 \\
\hline Cheilodactylus fuscus & Morwong & 0 & 0 & 0.9 & 1 \\
\hline Gobiidae $^{a}$ & Goby & 0 & 0 & 1.9 & 0 \\
\hline Trachurus spp. & Horsemackerel & 0 & 0 & 0 & 5.2 \\
\hline Chironemus marmoratus & Kelp fish & 0 & 0 & 0 & 3.6 \\
\hline Acanthistius ocellatus & Wirrah & 0 & 0 & 0 & 1.5 \\
\hline Pseudolabrus spp. ${ }^{\text {a }}$ & Wrasse & 0 & 0 & 0 & 0.5 \\
\hline Pictalabrus laticlavius & Wrasse & 0 & 0 & 0 & 0.5 \\
\hline Achoerodus viridus & Blue groper & 0 & 0 & 0 & 0.5 \\
\hline Siganus spinosus ${ }^{\text {a }}$ & Rabbit fish & 0 & 0 & 0 & 0.5 \\
\hline Anoplocarpus spp. ${ }^{\mathrm{a}}$ & Box fish & 0 & 0 & 0 & 0.5 \\
\hline Aulopus purpurissatus & Sergeant baker & 0 & 0 & 0 & 0.5 \\
\hline Parma microlepis & White ear & 0 & 0 & 0 & 0.5 \\
\hline Upeneicthys lineatus & Goat fish & 0 & 0 & 0 & 0.5 \\
\hline Dasyatis spp. & Stingray & 0 & 0 & 0.9 & 0 \\
\hline Orectolobus ornatus & Wobbegong & 0.7 & 0 & 0 & 0 \\
\hline Heterondontus portusjacksoni & Port Jackson Shark & 0 & 0 & 0 & 0.5 \\
\hline Total number of fish & & 142 & 108 & 108 & 192 \\
\hline Total number of groups & & 15 & 11 & 18 & 27 \\
\hline
\end{tabular}


Table 6. Analyses of mean numbers of fish caught per $2 \mathrm{~km}$ (Designs A and B, see Table 1), using untransformed data. Results of Cochran's tests are given $(C)$

\begin{tabular}{|c|c|c|c|c|c|c|c|}
\hline \multirow[t]{2}{*}{ Factor } & \multicolumn{3}{|c|}{$\begin{array}{l}\text { Design A } \\
C=0.27 \mathrm{~ns}\end{array}$} & & \multicolumn{3}{|c|}{$\begin{array}{c}\text { Design B } \\
C=0.27 \mathrm{~ns}\end{array}$} \\
\hline & $\mathrm{Df}$ & MS & $\mathrm{p}$ & & Df & MS & $\mathrm{p}$ \\
\hline Survey $(=\mathrm{Su})$ & 2 & 7.0 & ns & Holiday & 1 & 0.8 & ns \\
\hline Tide $(=\mathrm{Td})$ & 1 & 51.4 & $\cdot$ & Tide & 1 & 8.3 & ns \\
\hline Time $(=\operatorname{Tm})$ & 2 & 158.5 & $\cdots$ & Time & 2 & 135.8 & $\cdots$ \\
\hline Site $(=\mathrm{Si})$ & 1 & 65.4 & $\cdot$ & Site & 1 & 81.4 & $\cdots$ \\
\hline $\mathrm{Su} \times \mathrm{Td}$ & 2 & 57.0 & ns & Ho $\times \mathrm{Td}$ & 1 & 67.0 & $\because$ \\
\hline $\mathrm{Su} \times \mathrm{Tm}$ & 4 & 11.1 & ns & Ho $\times \operatorname{Tm}$ & 2 & 7.1 & ns \\
\hline $\mathrm{Su} \times \mathrm{Si}$ & 2 & 29.3 & ns & $\mathrm{Ho} \times \mathrm{Si}$ & 1 & 9.5 & ns \\
\hline$T d \times T m$ & 2 & 19.4 & ns & $\mathrm{Td} \times \mathrm{Tm}$ & 2 & 62.0 & $\cdots$ \\
\hline $\mathrm{Td} \times \mathrm{Si}$ & 1 & 114.4 & $\cdots$ & $\mathrm{Td} \times \mathrm{Si}$ & 1 & 14.6 & ns \\
\hline $\mathrm{Tm} \times \mathrm{Si}$ & 2 & 27.9 & ns & $\mathrm{Tm} \times \mathrm{Si}$ & 2 & 88.7 & $\cdots$ \\
\hline $\mathrm{Su} \times \mathrm{Td} \times \mathrm{Tm}$ & 4 & 57.4 & $\cdots$ & Ho $\times \mathrm{Td} \times \mathrm{Tm}$ & 2 & 15.1 & ns \\
\hline $\mathrm{Su} \times \mathrm{Td} \times \mathrm{Si}$ & 2 & 3.2 & ns & $\mathrm{Ho} \times \mathrm{Td} \times \mathrm{Si}$ & 1 & 24.8 & ns \\
\hline $\mathrm{Su} \times \mathrm{Tm} \times \mathrm{Si}$ & 4 & 20.6 & ns & $\mathrm{Ho} \times \mathrm{Tm} \times \mathrm{Si}$ & 2 & 1.7 & ns \\
\hline $\mathrm{Td} \times \mathrm{Tm} \times \mathrm{Si}$ & 2 & 37.1 & $\cdot$ & $\mathrm{Td} \times \operatorname{Tm} \times \mathrm{Si}$ & 2 & 5.0 & ns \\
\hline $\mathrm{Su} \times \mathrm{Td} \times \mathrm{Tm} \times \mathrm{Si}$ & 4 & 16.5 & ns & $\mathrm{Ho} \times \mathrm{Td} \times \mathrm{T}_{\mathrm{m}} \times \mathrm{Si}$ & 2 & 45.5 & $\cdot$ \\
\hline Residual & 36 & 11.2 & & Residual & 24 & 10.2 & \\
\hline
\end{tabular}

Table 7. Organisms, other than fish, taken from sites around Sydney during 24 mo. Numbers of replicates from which the total numbers are derived are given in brackets (of 48 replicates for summer and winter 1986-87; 24 for summer 1987-88; 30 for summer 1989)

\begin{tabular}{|c|c|c|c|c|c|c|c|c|}
\hline \multirow{2}{*}{$\begin{array}{l}\text { Group } \\
\text { Molluscs }\end{array}$} & \multicolumn{2}{|c|}{$\begin{array}{l}\text { Summer } \\
1986-87\end{array}$} & \multicolumn{2}{|c|}{$\begin{array}{c}\text { Winter } \\
1987\end{array}$} & \multicolumn{2}{|c|}{$\begin{array}{l}\text { Summer } \\
1987-88\end{array}$} & \multicolumn{2}{|c|}{$\begin{array}{c}\text { Summer } \\
1989\end{array}$} \\
\hline & & & & & & & & \\
\hline Turbo torquatus & 76 & (2) & 1 & (1) & 20 & (1) & 307 & (5) \\
\hline Thais orbita & 0 & & 13 & (2) & 0 & & 100 & (1) \\
\hline Morula marginalba & 0 & & 0 & & 2 & (1) & 1 & (1) \\
\hline Cellana tramoserica & 623 & (3) & 1 & (1) & 4 & (2) & 5 & (2) \\
\hline Patella peroni & 0 & & 0 & & 0 & & 25 & (1) \\
\hline Haliotis ruber & 5 & $(2)$ & 10 & (1) & 0 & & 0 & \\
\hline Austrocochlea constricta & 0 & & 0 & & 24 & $(2)$ & 25 & (2) \\
\hline Cabestana spengleri & 0 & & 0 & & 3 & (1) & 31 & (5) \\
\hline Mussel & 0 & & 0 & & 1 & (1) & 0 & \\
\hline Bembicium nanum & 0 & & 0 & & 0 & & 6 & $(2)$ \\
\hline Littorina unifasciata & 0 & & 0 & & 0 & & 5 & (1) \\
\hline \multicolumn{9}{|l|}{ Echinoderms } \\
\hline Echinoids & 0 & & 15 & $(2)$ & 40 & (1) & 59 & (3) \\
\hline Patiriella spp. & 0 & & 5 & (1) & 0 & & 17 & (1) \\
\hline \multicolumn{9}{|l|}{ Decapods } \\
\hline Grapsid crabs & 124 & (13) & 15 & (5) & 21 & $(\vec{f})$ & 78 & (13) \\
\hline Jasus verreauxi & 0 & & 1 & (1) & 0 & & 0 & \\
\hline Palaemon spp. & 0 & & 0 & & 3 & (1) & 0 & \\
\hline \multicolumn{9}{|l|}{ Ascidians } \\
\hline Pyura stolonifera & 387 & (14) & 412 & $(10)$ & 155 & $(10)$ & 82 & (7) \\
\hline
\end{tabular}

Few fish were caught early in the day, primarily because numbers of fishermen were very small at this time. Interactions involving all 4 factors of survey, time, tide and site were significant (Table 6). Thus, more fish were caught on some occasions than others, but in no predictable way according to the 4 factors. A complicated pattern was also found in designs which com- pared the number of fish caught in school holidays and term-time; a 4-way interaction was found between tide, time, holidays and sites. Individual species of fish could not be analysed because of small numbers and heterogeneous variances.

A large percentage of fishermen took bait from the shore $(34 \%$ of all fishermen sampled in Designs A \& B). 

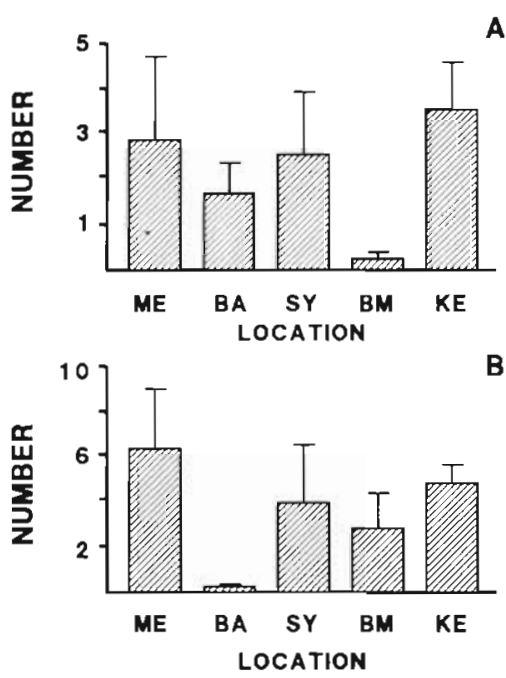

Fig. 7. Numbers of people affecting the shore at 5 locations along the coast of NSW in (A) summer and (B) winter 1988 (means $+\mathrm{SE}) ; \mathrm{ME}=$ Merimbula, $\mathrm{BA}=$ Batemans Bay, $\mathrm{SY}=$ Sydney, BM = Boomerang Beach, $\mathrm{KE}=$ Kempsey

A larger proportion of fishermen took bait from the shore at Bondi $(80.4 \%, \mathrm{n}=226)$ than at Cronulla $(19.6 \%, \mathrm{n}=55)$. At Bondi, $46 \%$ used green algae (Ulva \& Enteromorpha) from the shore as bait. In contrast, at Cronulla, only $10.7 \%$ used aigae as bait.

Intertidal organisms (Table 7) were taken for bait, food and even decorations (see below). Solitary ascidians, crabs and gastropods ranked as the most heavily exploited groups; these animals are prized as bait. Most of the solitary ascidians were taken during low tide $(80.6 \%, \mathrm{n}=1113)$. Crabs appeared to be taken regardless of the state of the tide (High $41.4 \%$, Low $58.6 \%, \mathrm{n}=179$ ). Numbers of the other organisms were too small for detailed analyses.
Some intertidal animals were taken in such large numbers that they were severely depleted in a localised area. For example, 600 limpets were taken by one man to decorate a swimming pool! The exploitation of some organisms was probably underestimated in the surveys because fishermen often gather bait as they need it.

\section{Activity of humans - coast of NSW}

No significant differences in numbers of people affecting the shore were found among 5 locations along a $1000 \mathrm{~km}$ stretch of the coast of NSW on either of 2 occasions (Fig. 7. Table 8). Trends in the numbers of people at different locations also changed between occasions (Fig. 7); large differences were found amongst sites within the different locations during summer and winter (Table 8 ). Fishermen, who made up the greatest proportion of people affecting the shore, showed the same pattern (Table 8 ).

The numbers of people who did not affect the shore were not significantly different among locations along the coast of NSW on 2 occasions.

\section{Organisms affected by humans - coast of NSW}

The species of fish that were taken in greatest numbers along $1000 \mathrm{~km}$ of the coast of NSW closely reflected those taken in greatest numbers around Sydney (Table 9). Girellids, sparids and pomatomids ranked as the most important components of the catch. Mackerel were also taken in large numbers, but were primarily used as bait. Some differences were found at

Table 8. Analyses of mean numbers of people per $1 \mathrm{~km}$. Design $\mathrm{D}$; see Table 1 ; data were transformed to $\ln (x+1)$ to stabilise variances

\begin{tabular}{|c|c|c|c|c|c|c|c|}
\hline \multicolumn{8}{|l|}{ Summer 1988} \\
\hline \multirow[t]{2}{*}{ Factor } & \multirow[b]{2}{*}{ Df } & \multicolumn{2}{|c|}{$\begin{array}{l}\text { People affecting shore } \\
\qquad C=0.28 \mathrm{~ns}\end{array}$} & \multicolumn{2}{|c|}{$\begin{array}{c}\text { Total fishermen } \\
C=0.27 \mathrm{~ns}\end{array}$} & \multicolumn{2}{|c|}{$\begin{array}{l}\text { People not affecting shore } \\
\qquad C=0.33 \mathrm{~ns}\end{array}$} \\
\hline & & MS & $\mathrm{p}$ & MS & $\mathrm{p}$ & MS & $\mathrm{p}$ \\
\hline Location $(=\mathrm{L})$ & 4 & 1.7 & $\mathrm{~ns}$ & 2.00 & ns & 2.7 & ns \\
\hline Site (L) & 15 & 1.4 & $\cdots$ & 1.2 & $\cdots$ & 0.7 & ns \\
\hline Residual & 40 & 0.35 & & 0.35 & & 0.8 & \\
\hline \multicolumn{8}{|l|}{ Winter 1988} \\
\hline \multirow{2}{*}{ Factor } & \multicolumn{3}{|c|}{$\begin{array}{l}\text { People affecting shore } \\
\qquad C=0.24 \mathrm{~ns}\end{array}$} & \multicolumn{2}{|c|}{$\begin{array}{l}\text { Total fishermen } \\
C=0.22 \mathrm{~ns}\end{array}$} & \multicolumn{2}{|c|}{$\begin{array}{l}\text { People not affecting shore } \\
\qquad C=0.20 \mathrm{~ns}\end{array}$} \\
\hline & Df & MS & $\mathrm{p}$ & MS & $\mathrm{p}$ & MS & $\mathrm{p}$ \\
\hline Location $(=\mathrm{L})$ & 4 & 2.8 & ns & 3.3 & ns & 2.0 & ns \\
\hline Site (L) & 15 & 1.1 & ns & 1.4 & $\cdots$ & 1.1 & ns \\
\hline Residual & 40 & 0.6 & & 0.4 & & 0.4 & \\
\hline
\end{tabular}


Table 9. Proportional representation (\% data) of fish captured by recreational fishermen along the coast of NSW in 1988

\begin{tabular}{|c|c|c|c|}
\hline Group & Common name & Summer & Winter \\
\hline Girella spp. & Luderick/blackfish & 18.2 & 25.9 \\
\hline Acanthopagrus australis & Bream & 20.8 & 17.2 \\
\hline Chrysophrys auratus & Snapper & 0 & 5.2 \\
\hline Sillago ciliata & Whiting & 6.9 & 0 \\
\hline Scorpis spp. & Sweep & 0.6 & 4.3 \\
\hline Kyphosus sydneyanus & Drummer & 0.6 & 3.4 \\
\hline Aplodactylidae & Sea carp & 1.9 & 0.9 \\
\hline Chironemus marmoratus & Kelp fish & 0 & 3.4 \\
\hline Ophthalmolepis lineolatus & Maori wrasse & 0 & 1.7 \\
\hline Achoerodus viridus & Blue groper & 1.9 & 0 \\
\hline Pseudolabrus gymnogenis & Scarlet wrasse & 0 & 4.3 \\
\hline Dotalabrus auranticus & Castelnau's wrasse & 0 & 0.9 \\
\hline Pseudolabrus tetricus & Girdled wrasse & 0 & 0.9 \\
\hline Gymnothorax spp. & Moray eel & 0.6 & 0 \\
\hline Pomatomus saltator & Tailor & 17.0 & 20.6 \\
\hline Trachurus spp. $^{\mathrm{a}}$ & Horse mackerel & 9.4 & 6.0 \\
\hline Seriola grandis & Kingfish & 0.6 & 0 \\
\hline Sarda australis & Bonito & 5.0 & 0 \\
\hline Katsuwonis pelamis & Skipjack & 1.9 & 0 \\
\hline Scomber australasicus ${ }^{\text {a }}$ & Blue mackerel & 11.3 & 0.9 \\
\hline Monacanthidae & Leatherjackets & 1.9 & 0 \\
\hline Pseudocaranx dentex ${ }^{a}$ & Trevally & 1.2 & 7.8 \\
\hline Acanthistius ocellatus & Wirrah & 0 & 1.7 \\
\hline Serranidae & Groper & 0.6 & 1.7 \\
\hline Cheilodactylus fuscus & Red morwong & 0.6 & 0 \\
\hline Total number of fish & & 160 & 117 \\
\hline Number of groups & & 18 & 17 \\
\hline a Fish generally taken as ba & & & \\
\hline
\end{tabular}

Table 10. Organisms other than fish taken from all sites $(20 \mathrm{~km}$ of coastline; searched 3 times) along the coast of NSW in 1988. Brackets indicate the number of replicates (of 60 in each season) from which the numbers were derived; + indicates parts of individuals that could not be counted

\begin{tabular}{|c|c|c|c|c|c|}
\hline \multirow{2}{*}{$\frac{\text { Taxon }}{\text { Cellana tramoserica }}$} & \multirow{2}{*}{ Common names } & \multicolumn{2}{|c|}{ Summer } & \multicolumn{2}{|c|}{ Winter } \\
\hline & & 10 & (1) & 20 & (3) \\
\hline Grapsids & Crabs & 46 & (5) & 49 & (5) \\
\hline Pyura stolonifera & Solitary ascidians (cunjevoi) & 15 & (3) & +10 & (3) \\
\hline Octopus spp. & Octopus & 0 & & 1 & (1) \\
\hline Errant polychaetes & Worms & 0 & & 6 & (1) \\
\hline
\end{tabular}

different times of the year. Tuna Katsuwonis pelmanis and Sarda australis and blue mackerel Scomber australasicus were most often caught in summer when warm waters bathe the coast of NSW as far south as Merimbula (Tate 1988).

Organisms in intertidal habitats were also taken by people along the coast of NSW (Table 10). Groups of organisms taken in greatest numbers included limpets, crabs and ascidians. As in detailed studies of the Sydney area, recreational fishermen attempted to catch herbivorous girellids using green algae for bait.

\section{DISCUSSION}

\section{Patterns of exploitation by humans}

Reef-associated and pelagic fish and intertidal organisms were taken in large numbers by humans along the coast of New South Wales. The edible fish most commonly taken by fishermen, in the vicinity of Sydney and along the coast of NSW, were herbivorous girellid fish and carnivorous sparid fish. A wide variety of other fishes was captured and some of these were 
used for bait (e.g. mado and sweep). Some seasonality in catches of tuna was found along the coast of NSW where almost all of the fish captured were taken in summer. Tuna follow the warm water as it moves southwards (e.g. Clement 1978), so the largest catches of these fish would be expected during the summer.

Few comparative data have published on the fish captured by recreational fishermen in open coastal marine environments. Most of the literature on the activities of people affecting the shore is concerned with intertidal invertebrates (e.g. Castilla \& Duran 1985, Hockey \& Bosman 1986).

People took gastropods, ascidians, crabs and some echinoderms from intertidal and immediate subtidal habitats. Although some echinoids and gastropods were used as food, most were used as bait for fishing. This contrasts with studies in other parts of the world where intertidal organisms are primarily utilised as food, for example in South America (Moreno et al. 1984, Castilla \& Bustamante 1989) and South Africa (Siegfried et al. 1985, Hockey \& Bosman 1986). Although there are anecdotal accounts of some ethnic groups being primarily responsible for taking intertidal organisms for food in NSW, race was not considered in this survey. Hockey et al. (1988) found that $37 \%$ of ethnic Africans on the shore in Transkei (South Africa) collected intertidal organisms. Intertidal animals are an important source of protein for these people (Siegfried et al. 1985). In that study, only $4 \%$ of the ethnic Europeans on the shore collected intertidal organisms.

Taking large numbers of ascidians is unusual compared to other parts of the world (Duran et al. 1987, Hockey et al. 1988). Pyura stolonifera (cunjevoi) are commonly used as bait by fishermen in NSW. $P$. stolonifera are found in greatest abundance near the low tide mark. It is not surprising, therefore, that the largest numbers of ascidians were taken at low tide. The only other record of ascidians being taken by humans is by Duran et al. (1987), who noted skin-divers collecting them. Similar to our findings for $P$. stolonifera, Hockey \& Bosman (1986) reported that exploitation of intertidal organisms in South Africa was most severe lower on the shore.

Mean densities of up to 23 people $\mathrm{km}^{-1}$ were found affecting the shore in the Sydney region. People are therefore potentially important in determining the abundance and species composition of fishes and sedentary invertebrates associated with rocky reefs. Surveys in the Sydney region detected a number of patterns. Exploitation of rocky reefs is likely to be greatest on weekends during the summer, in the later half of the day. Accordingly, many of our estimates of exploitation rates along the coast of NSW were conservative. Peaks in the utilization of sandy beaches by humans have also been found during the later part of the day on weekends, in South Africa (van Herwerden et al. 1989). On one occasion, differences were found between school holidays and term-time in our study. Fishing is a popular pursuit of school children during the holidays.

Some sites (e.g. Bondi) appeared to attract more people affecting the shore than did others (e.g. Cronulla). Although large numbers of people were found affecting the shore over $2 \mathrm{~km}$ stretches at both locations, detailed mapping of the position of people indicated that they were clumped on scales of 50 and $100 \mathrm{~m}$. This indicated that the magnitude of exploitation in favourite fishing spots is likely to be much greater than the overall mean values. The detailed positions of fishermen were not mapped in surveys.

The number of people affecting the shore along the coast of NSW did not appear to be related to the proximity of large cities. Numbers of people at sites around Sydney were not significantly different from those at locations with a much smaller population (e.g. Kempsey). This was the case in winter and in summer. This is in marked contrast to the work done by Hockey et al. (1988), where people affecting the shore were found in greatest numbers opposite settlements with large populations. In NSW, the population appears to be much more mobile. Interviews with fishermen indicated that they often drive from the main centres to locations along the entire coast of NSW.

Activities of fishermen did not appear to be related to catch per unit effort. Although few fishermen were recorded early in the day, catch rates of fish then were no different from the middle of the day nor from late in the afternoon. Duran et al. (1987) published average values for the number of fish caught per hour by spearfishermen. In this survey, it was impossible to record the numbers of fish caught by spearfishermen because many of the divers were still in the water. Casual observations, while diving, indicate that the activity of spearfishermen around Sydney is patchy, but can be intense. They are usually restricted to shallow water $(<3 \mathrm{~m})$ and mostly spear aplodactylids, Cheilodactylus spp. and monacanthids.

\section{Ecological consequences of exploitation}

In other parts of the world it has been argued that man is a top predator in the intertidal zone of temperate rocky reefs (e.g. Castilla \& Duran 1985). A consequence of the removal of some organisms can be a change in assemblages on local reefs (Moreno et al. 1986, Hockey et al. 1988). Direct effects on fish and invertebrates may include the removal of large reproductively active individuals (e.g. limpets; Ortega 1987). The influence of this on the demography of these organisms has not 
been investigated. Apart from direct effects on the demography of organisms, there are a number of potential indirect effects caused by the removal of individuals. For example, the removal of grazers such as Cellana tramoserica from the shore may alter the biomass and species composition of algae to such an extent that other micrograzers cannot feed and sessile species are eliminated. Furthermore, some grazers may have increased survivorship in the absence of their competitors (Creese \& Underwood 1982, Underwood et al. 1983, Underwood 1984, 1985).

Duran \& Castilla (1989) found that the predatory gastropod Concholepas concholepas played a key role as an intertidal predator when protected from human exploitation. In the presence of humans, a monoculture of mussels was found on the shore; where humans were not allowed to collect the whelks, barnacles predominated. This scenario appears unlikely to happen in NSW. Although the intertidal predatory whelk Morula marginalba is abundant (Moran et al. 1984, Moran 1985, Fairweather 1988), the animals are small and few were taken by fishermen or foragers.

The intensity of direct and indirect effects of humans on intertidal organisms may depend on the availability of favoured prey. Siegfried et al (1985), for example, found that once humans removed large quantities of mussels (a favoured food) from the shore, a wide variety of other long-lived intertidal species was taken.

The removal of solitary ascidians Pyura stolonifera may have a serious direct effect on local populations, especially because large individuals are favoured as bait. The presence of large numbers of filter feeders may affect the settlement of other organisms (Young 1990). P. stolonifera are also an important substratum for the growth of algae in areas grazed by chitons and may be an important habitat for chitons (Otway 1989). The ascidians are also an important source of food for large intertidal and subtidal whelks (Underwood \& Fairweather 1986).

We can only speculate on the ecological consequences of removing temperate fish, because little is known on the fish associated with reefs in NSW. Apart from the direct effects, mentioned for intertidal animals, there are potential indirect effects. For example, the removal of carnivorous fish such as sparids may facilitate increased survivorship of subtidal benthic invertebrates such as urchins (Andrew \& Choat 1982, McClanahan \& Muthiga 1988) and gastropods. Herbivorous girellids and aplodactylids are abundant in shallow water (M.J.K. unpubl. data), The intensity and importance of feeding by fish on the demography of algae is poorly understood in temperate waters and requires investigation (Jones 1988, Jones \& Andrew 1990).

\section{Guidelines for management}

It is clear that a multifactorial approach is required to describe adequately the activities of humans on rocky reefs. Factors such as time of day, weekends versus weekdays and multiple sites need to be incorporated into surveys. It is difficult to control or stratify sampling to estimate some aspects of human behaviour, which probably explains the large residual variances in many of our analyses. For example, popular sporting events which are televised may deplete numbers of enthusiastic fishermen on some days. Differences in sea conditions often deter or enthuse people affecting the shore, but are very difficult to categorize accurately when they vary over short stretches of coastline. Differences in weather will also influence the numbers of people and their activities; in this study we examined patterns only during fine weather.

Most studies of recreational fishermen have focussed on the effects of man as a predator in exploited areas (Moreno et al. 1984, Duran \& Castilla 1989, Siegfried et al. 1985). Little attention has been given to the design of surveys which assess the effects of people on the shore. Aerial surveys were used (Hockey et al. 1988) to count numbers of people on rocky shores in South Africa during low tides. This approach can allow surveys of large areas of coastline over short periods. It does, however, limit the type of information that can be gathered. Hockey et al. (1988) differentiated ethnic African from Europeans and recorded the presence of people with fishing rods. They could not record with certainty whether people were affecting the shore, how long they had been on the shore, or the organisms taken and their size. Along the coast of NSW, numbers of people not affecting the shore (e.g. walkers) often exceeded those affecting the shore, especially during the middle of the day. If these 2 groups are not distinguished, human activities will be overestimated.

It can be argued that surveys of recreational fishermen (via creel surveys) should control for the experience of fishermen. Without personal knowledge of the fishermen, this is almost impossible to do. Moreover, fishermen pursue their recreational activities for a wide variety of reasons that do not necessarily relate experience to the number of fish taken for eating. Fedler \& Ditton (1986) found there was no such thing as an average recreational fisherman. The reasons for going fishing ranged from catching as many fish as possible (for eating) to catching and returning all fish. No allowance was made for the experience of individuals in our study.

Research on the activity of people affecting the shore in different parts of the world indicates that this type of information must be used to complement traditional 
statistics (Duran et al. 1987). Large numbers of commercial fish are taken by recreational fishermen in boats and from the shore. Furthermore, people often fish in habitats not usually exploited by commercial fishermen (e.g. shallow rocky reefs). Appropriate management of the recreational activities of humans may include a number of different approaches which can improve commercial and recreational fisheries in addition to protecting rocky reef habitats.

Sanctuaries which totally exclude people from the shore can facilitate increased harvests in adjacent fisheries (Davis \& Dodrill 1989) and provide refuges for the preservation of breeding populations (Castilla \& Bustamante 1989). Protected areas appear to facilitate increased densities of fish and a greater proportion of large individuals compared to unprotected areas (e.g. McCormick \& Choat 1987). Furthermore, protected areas allow measurements of the intensity and importance of interactions among animals in the absence of humans (e.g. Castilla \& Bustamante 1989).

The only way that the effect of humans on the shore can be determined is to compare exploited and unexploited sites. Multiple areas of protected and unprotected sites would give the most accurate picture of the effect of humans (Underwood 1989).

Rotational cropping has been advocated by Hockey \& Bosman (1986) for sustaining intertidal resources along the coast of South Africa. The frequency of rotation would vary according to the demography of organisms on the shore. Siegfried et al. (1985), for example, advised a 14 mo rotational cropping basis for mussels due to the fast productivity of the animals. Decisions on timing of rotation are more difficult where a number of species is exploited.

Marine protected areas only work where policing is adequate and there is support for the idea from the local inhabitants. Exploitation of organisms can be very heavy over a short time period, especially in intertidal regions. The findings from our study indicate the most profitable and, where appropriate, cost-effective times for policing areas. Late morning to dusk and on weekends would be best, especially at locations known to attract fishermen. Policing during low tide would be best for protecting Pyura stolonifera, while spearfishermen during summer pose the greatest threat to fish associated with reefs.

Acknowledgements. This research was supported by a Marine Sciences and Technology Crant and grants from the Australian Research Council and the Institute of Marine Ecology of the University of Sydney (to A.J.U.). We thank $M$. Atkinson, K. Jenkins, D. Liszka, S. McNeill, M. Millstone, A. Montgomery and W. Steel for their assistance with fieldwork. Helpful criticisms of the manuscript were given by Drs P. G. Fairweather and P. A. Underwood.

\section{LITERATURE CITED}

Andrew, N. L., Choat, J. H. (1982). The influence of predation and conspecific adults on the abundance of juvenile Evechinus chloroticus Echinoidea: Echinometridae). Oecologia 54: 80-87

Beamish, B. (1986). The Canadian wildlife federation's study of Canada's freshwater fisheries: an overview. Recreational Fisheries Conference 1986. Can. Spec. Publ. Fish. Aquat. Sci. 97: 121-125

Castilla, J. C., Bustamante, R. H. (1989). Human exclusion from rocky intertidal of Las Cruces, central Chile: effects on Durvillaea antarctica (Phaeophyta, Durvilleales). Mar. Ecol. Prog. Ser. 50: 203-214

Castilla, J. C., Duran, L. R. (1985). Human exclusion from the rocky intertidal zone of central Chile: the effects of Concholepas concholepas (Gastropoda). Oikos 45: 391-399

Catterall, C. P., Poiner, I. R. (1987). The potential impact of human gathering on shellfish populations, with reference to some N. E. Australian intertidal flats. Oikos 50: 114-122

Choat, J. H., Ayling, A. M. (1987). The relationship between habitat structure and fish faunas. J. exp. Mar. Biol. Ecol. 110: $257-284$

Clement, 1. T. (1978). School fish sightings around New Zealand, 1976-1977. N. Z. Fish. Res. Div. Occas. Pub., No 15

Cowan, R. K. (1985). Large scale patterns of recruitment by labrid Semicossyphus pulcher: causes and implications. J. mar. Res. 35: 491-504

Creese, R. G., Underwood, A. J. (1982). Analysis of inter- and intra-specific competition amongst limpets with different methods of feeding. Oecologia 53: 337-346

Davis, G. E., Dodrill, J. W (1989). Recreational fishery and population dynamics of spiny lobsters, Panulirus argus, in Florida Bay, Everglades National Park 1977-1980. Bull. mar. Sci. 44: 78-88

Duran, L. R., Castilla, J. C. (1989). Variation and persistence of the middle rocky intertidal community of central Chile, with and without human harvesting. Mar. Biol. 103: 555-562

Duran, L. R., Castilla, J. C., Oliva, D. (1987). Intensity of human predation on rocky shores at Las Cruces in Central Chile. Environ. Cons. 14: 143-149

Fairweather, P. G. (1988). Predation can increase variability in the abundance of prey on seashores. Oikos 53: 87-92

Fedler, A. J., Ditton, R. B. (1986). A framework for understanding the consumptive orientation of recreational fishermen. Envir. Mgmt 10: 221-227

Gartside, D. F. (1986). Recreational fishing. Proc. Nat. Conf. coast. Manage. 1: 101-106

Gehrke, P. C. (1988). Feeding energetics and angling catches of spangled perch, Leiopotherapon unicolor (Gunther 1859), (Percoidei: Tereponidae). Aust. J. mar. Freshwat. Res. 39: 569-577

Higgins, T. (1986). Resource conservation issues. Recreational Fisheries Conference 1986. Can. Spec. Publ. Fish. Aquat. Sci. 97: 131-134

Hockey, P. A. R., Bosman, A. L. (1986). Man as an intertidal predator in Transkei: disturbance, community convergence and management of a natural food resource. Oikos 46: 3-14

Hockey, P. A. R., Bosman, A. L., Siegfried, W. R. (1988). Patterns and correlates of shellfish exploitations by coastal people in Transkei: an enigma of protein production. J. appl. Ecol. 25: 353-363

Hume, D. J. (1987). Creel survey report: 1986-87. Fisheries Management Report, Victoria, Australia, No 18

Jones, G. P. (1988). Ecology of reef fish of north-eastern New Zealand. N.Z. J. mar. Freshwat. Res. 22: 445-462

Jones, G. P., Andrew, N. L. (1990). Herbivory and patch 
dynamics in the kelp forests of temperate Australia: the roles of fish and sea urchins. Aust. J. Ecol. 15: 505-520

McClanahan, T. R., Muthiga, N. A. (1989). Changes in Kenyan coral reef community structure and function due to exploitation. Hydrobiologia 166: 269-276

McCormick, M. I., Choat, J. H. (1987). Estimating total abundance of a large temperate reef fish using visual striptransects. Mar. Biol. 96: 469-478

Moran, M. J. (1985). Distribution and dispersion of the predatory intertidal gastropod, Morula marginalba. Mar. Ecol. Prog. Ser. 22: 41-52

Moran, M. J., Fairweather, P. G., Underwood, A. J. (1984). Growth and mortality of the predatory intertidal whelk Morula marginalba Blainville (Muricidae): the effects of different species of prey. J. exp. mar. Biol. Ecol. 75: 1-17

Moreno, C. A., Lunecke, K. M., Lepez, M. I. (1986). The response of an intertidal Concholepas concholepas (Gastropoda) population to protection from man in southern Chile and the effects on benthic sessile assemblages. Oikos 46: 359-364

Moreno, C. A., Sutherland, J. P., Jara, F. H. (1984). Man as a predator in the intertidal zone of central Chile. Oikos 42: $155-160$

Ortega, S. (1987). Habitat segregation and temporal variation in some tropical intertidal populations. J. exp. mar. Biol. Ecol. 113: 247-266

Otway, N. M. (1989). The effects of grazing by chitons on mid and low-shore intertidal communities. Ph. D. thesis, University of Sydney

Rice, K. (1986). National statement on recreational fisheries. Recreational Fisheries Conference 1986. Can. Spec. Publ. Fish. Aquat. Sci. 97: 127-130

Siegfried, W. R., Hockey, P. A. R., Growe, A. A. (1985). Exploitation and conservation of brown mussel stocks by coastal people of Transkei. Environ. Conserv. 12: 303-307

Tate, P. M. (1988). Monthly mean surface thermal structure in the Tasman Sea from satellite imagery 1979-84. Aust. J. mar. Freshwat. Res. 201. 579-588

Underwood, A. J. (1980). The effects of grazing by gastropods

This article was presented by C. H. Peterson, Morehead City, N. Carolina, USA and physical factors on the upper limits of distribution of intertidal macroalgae. Oecologia 46: 201-213

Underwood, A. J. (1984). Vertical and seasonal patterns in competition for microalgae between intertidal gastropods. Oecologia 64: 211-222

Underwood, A. J. (1985). Physical factors and biological interactions: the necessity and nature of ecological experiments. In: Moore, P. G., Seed R. (eds.) The ecology of rocky coasts. Hodder \& Stoughton, London, p. 371-190

Underwood, A. J. (1989). The analysis of stress in natural populations. Biol. J. Linn. Soc. 37: 51-78

Underwood, A. J., Denley, E. J., Moran, M. J. (1983). Experimental analyses of the structure and dynamics of midshore rocky intertidal communities in New South Wales. Oecologia 56: 202-219

Underwood, A. J., Fairweather, P. G. (1986). Intertidal communities: do they have different ecologies or different ecologists? Proc. Ecol. Soc. Aust. 14: 7-16

Underwood, A. J., Jernakoff, P. (1981). Interactions between algae and grazing gastropods in the structure of a lowshore algal community. Oecologia 48: 221-233

Underwood, A. J., Jernakoff, P. (1984). The effects of tidal height, wave-exposure, seasonality and rock-pools on grazing and the distribution of intertidal macroalgae in New South Wales. J. exp. mar. Biol. Ecol. 75: 71-96

Underwood, A. J., Kennelly, S. J. (1990). Pilot studies for designs of surveys of human disturbance of intertidal habitats in New South Wales. Aust. J. mar. Freshwat. Res. 41: $165-173$

van Herwerden, L., Griffiths, C. L., Blaine, M., du Plessis, C. (1989). Patterns of shore utilization in a metropolitan area: The Cape Peninsula, South Africa. Ocean Shore Manage. 12: $331-346$

Yapp, G. A. (1986). Aspects of populations, recreation, and management of the Australian coastal zone. Coast. Zone Manage. J. 14: 47-66

Young, C. M. (1990). Larval predation by epifaunal invertebrates: scales of measurable effects. Aust. J. Ecol. 15: $413-426$

Manuscript first received: December 28, 1990

Revised version accepted: March 7, 1991 